\title{
ERRATUM
}

Frank Zufall • Kyrill Ukhanov • Philippe Lucas •

Trese Leinders-Zufall

\section{Neurobiology of TRPC2: from gene to behavior}

Published online: 7 December 2005

C) Springer-Verlag 2005

\section{Pflugers Arch - Eur J Physiol (2005) 451:61-71}

The author list for the article by Zufall et al, "Neurobiology of TRPC2: from gene to behavior" was incomplete. The correct list of authors is as follows:

Zufall, F, Ukhanov, K, Lucas, P, Liman, ER*, LeindersZufall, T

*Department of Biological Sciences, University of Southern California.

Some of the text in this article was reprinted, with permission, from Liman, E.R., and Zufall F. (2004). Transduction channels for pheromone detection in the vomeronasal organ. In Transduction channels in sensory cells, S. Frings and J. Bradley eds. Wiley-VCH: Weinheim, Germany.

The online version of the original can be found at http://dx.doi.org $10.1007 / \mathrm{s} 00424-005-1432-4$.

F. Zufall $(\bowtie) \cdot$ K. Ukhanov $\cdot$ P. Lucas $\cdot$ T. Leinders-Zufall Department of Anatomy and Neurobiology and Program in Neuroscience, University of Maryland School of Medicine, 20 Penn Street,

Baltimore, MD 21201-1509, USA

e-mail: fzufa001@umaryland.edu

Tel.: +1-410-7063312

Fax: $+1-410-7067068$

P. Lucas

INRA, Unita de Phytopharmacie et des Madiateurs Chimiques, 78026 Versailles, Cedex, France 